\title{
CROP RAIDING STATUS BY ASSAMESE MONKEYS (Macaca assamensis) ALONG THE KALIGANDAKI RIVER, WESTERN NEPAL
}

\author{
Suvas Chandra Ghimire ${ }^{1}$, Mukesh Kumar Chalise ${ }^{2, *}$ \\ ${ }^{1}$ Amrit Science Campus, Tribhuvan University, Kathmandu, Nepal \\ ${ }^{2}$ Central Department of Zoology, Tribhuvan University, Kathmandu, Nepal \\ *Corresponding author: mukesh57@hotmail.com
}

(Received: December 6, 2018; Revised: April 20, 2019; Accepted: April 26, 2019)

\begin{abstract}
A study on Assamese monkeys (Macaca assamensis) in Kaligandaki river basin at Ramdi of Palpa and Syangja districts of western Nepal was performed. The field study was conducted from February 2015 to January 2016 spending 1804 hours to explore the ecology and feeding behavior of Assamese macaque. The study mainly focused the Ramdi village area. A total of 24 individuals of Assamese monkeys were counted towards Palpa district and 18 individuals were counted towards Syangja district. Crop raiding status was examined each year by questionnaire survey method for local household villagers as well as direct observation by the researcher. It was found that maize $(47.14 \%)$ was the highest raided among the crops, followed by fruits $(16.43 \%)$, wheat $(11.13 \%)$, millet $(5.72 \%)$, rice $(4.58 \%)$, potato $(4.27 \%)$, lentil $(4.07 \%)$, mustard $(1.26 \%)$, pumpkin $(1.14 \%)$, bread $(0.96 \%)$, brown lentil $(0.81 \%)$, broad beans $(0.80 \%)$, sesame $(0.60 \%)$, black pulses $(0.35 \%)$, dal $(0.20 \%)$, cauliflower $(0.14 \%)$, tomato $(0.1 \%)$, egg $(0.1 \%)$, samosa $(0.1 \%)$ and gram $(0.1 \%)$.
\end{abstract}

Keywords: Macaca assamensis, Crop raid, Questionnaires, Local villagers, Kaligandaki riverside

\section{INTRODUCTION}

Among several species of macaques found in the world, three species have been reported from Nepal. These are the Rhesus macaque (Macaca mulatta, Zimmerman 1780), Hanuman Langur (Semnopithecus entellus, Dufresne 1797) and the Assamese macaque (Macaca assamensis, McClelland 1839). Information on the distributions, behavioral ecology and conservation status of these species are provided by Bishop (1979), Southwick et al. (1982), Johnson et al. (1988), Jackson (1990), Chalise (1995, 1997, 1998, 1999, 2000, 2000a, 2000b), Chalise et al. (2001) and Khanal et al. 2018. Macaca assamensis inhabits the foot-hills of the Himalayas and the adjoining mountain chains of southeast Asia including Nepal, Bhutan, north-eastern India, northern and eastern Burma, southern China, northern and western Thailand, Laos and northern Vietnam, besides an isolated record in south-western Bangladesh.

The species of Assamese macaque was recorded from north Thailand ranging from $610 \mathrm{~m}$ to $1830 \mathrm{~m}$ above the sea level (asl) (Sanjay et al. 2003). Chalise (2013) recorded it from $284 \mathrm{~m}$ asl in Abukhaireni, Tanahu to $2350 \mathrm{~m}$ asl in Langtang of Nepal. It was reported to cover wider geographic ranges, with fragmented population, distributed along rivers in the tropical and subtropical areas. In Nepal, the reported areas of Assamese monkeys covered Kankai valley of Ilam, Sabhaya valley and its range further extended west to Makalu-Barun National Park, Melamchi, Langtang National Park (Chalise 2003), Nagarjun area of Shivapuri Nagarjun National Park, Makwanpur, Dhading, Myagdi, Ramdi of Palpa and
Syangja districts, Achham district (Chalise, 2003 \& 2008; Wada, 2005), Baglung and Parbat to Chamelia river basin at $1607 \mathrm{~m}$ asl of Api Nampa Conservation Area (Chalise, 2013).

Assamese monkeys have been categorized as endangered species by International Union for Conservation of Nature (IUCN) red list category and one of the protected species by National Parks and Wildlife Conservation Act 1973 due to the low population and conservation threats (Jnawali et al. 2011). They are kept as Appendix II of Convention on International Trade in Endangered Species (CITES) (Chalise 2013).

\section{MATERIALS AND METHODS}

\section{Study area}

The study was carried out in Ramdi village area of Palpa and Syangja districts of Lumbini and Gandaki zones, respectively. It lies in the western developmental region of Nepal, but according to the constitution of Nepal 2015, Palpa district lies in Province No. 5 and Syangja district lies in Province No. 4. The study area, Ramdi village area lies about $27 \mathrm{~km}$ east of Tansen of Palpa district, at the mid-point of Siddhartha (Sunauli-Pokhara) Highway. The study area is situated between $27^{\circ} 54^{\prime} 9.34^{\prime \prime} \mathrm{N}$ latitude and $83^{\circ} 38^{\prime} 3$ " E longitude. The altitude is $433 \mathrm{~m}$ above the sea level.

This area is rich in biodiversity which may be due to presence of alluvial soil along the basin of Kaligandaki River and high productivity of tropical deciduous riverine forest (Chalise 2013). Mixed type of forest especially 
tropical deciduous riverine forest, sub-tropical grassland and sub-tropical evergreen forest are the forest types found in the study area.

\section{Methods}

Information on the data of crop raiding were collected each year from local household villagers as per the pre-set questions format as well as by direct observation of the researcher. More than 200 respondents were randomly selected from the people living around the Ramdi area for this study. The pre-set questionnaires formats were used to get the information on human-monkey conflicts. The respondents were interviewed separately to ensure the independence of the individual response. To minimize the bias, questions were asked to the villagers on the expected production of crops without crop raiding and the amounts of crops after raiding. The data were compiled together and calculated in terms of percentages.

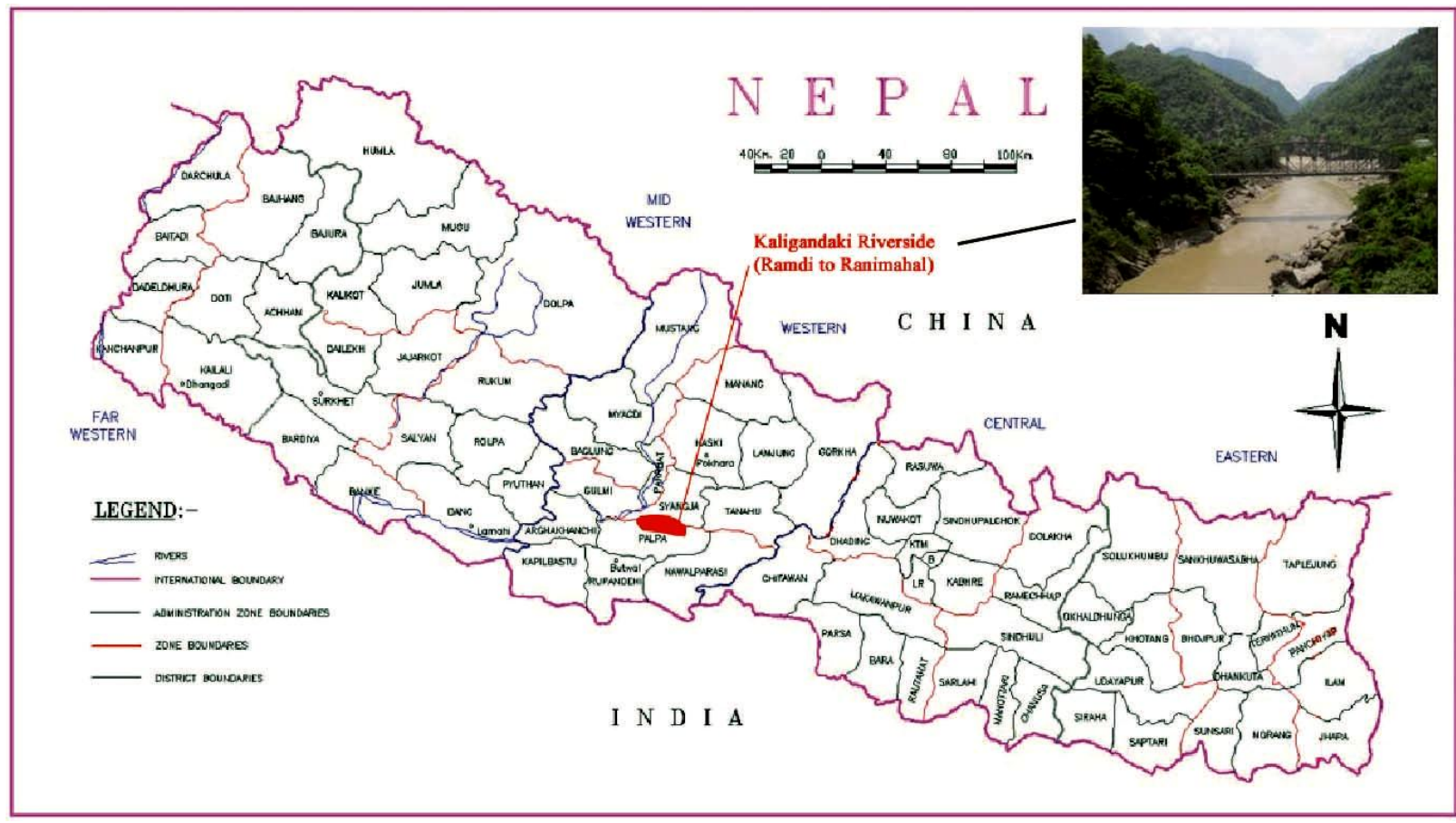

Fig. 1. Location of study area (Ramdi area) in the map of Nepal

\section{RESULTS}

In this study all the wards of Darlamdanda village development committee and Khanichhap village development committee of Palpa district and Malunga Tunibot village development committee of Syangja district were found affected by monkey species of Rhesus, Langur and Assamese. Among all these wards, Darlamdanda-2, Ramdi village; Darlamdanda-6, Sunadi village; Khanichhap-2, Ramdi village; Khanichhap-2, Bardanda village; Khanichhap-9, Padhari village of Palpa district and Malunga Tunibot-6, Ramdi village of Syangja district were the most affected by the Assamese monkeys. According to 33 respondents of Darlamdanda-2, Ramdi village, a total of 18.98 quintals crop was damaged by the monkeys. The crop damaged in Darlamdanda-6, Sunadi village, according to 25 respondents was recorded 31.15 quintals. It was found 1.97 quintals of crop loss in Khanichhap-2, Ramdi village responded by 8 people. In Khanichhap-2, Bardanda village and in Khanichhap-9, Padhari village, the crop loss was recorded 2.3 quintals and 2.2 quintals, respectively. According to 29 respondents of Malunga Tunibot-6, Ramdi village, the total crop damage by the monkeys was found 42.04 quintals. The highest crop damage due to monkeys was recorded in the crop field of Raj Kumar Shrestha. The total of 11.4 quintals crop was damaged in his field which included 5.4 quintals maize, 1.8 quintals wheat, 1.8 quintals millet, 0.6 quintal fruits, 0.3 quintal lentil, 0.3 quintal broad beans and 1.2 quintals mustard. This huge loss may be due to the proximity of field to the forest being less than $100 \mathrm{~m}$.

The crop loss data were collected to make a generalized scenario of the area and calculated in average percentages. It was found that maize (Zea mays) was the highest raided crop, followed by fruits, wheat (Triticum aestivum), millet (Eleusine coracana), rice (Oryza sativa), potato (Solanum tuberosum), lentil (Lens culinaris), mustard (Brassica nigra), pumpkin (Cucurbita maxima), bread, brown lentil, broad beans (Vicia faba), sesame, black pulses (Vigna mungo), dal, cauliflower, tomato (Lycopersicum esculentum), egg, samosa and gram (Cicer arietinum). The percentage of crop raided was calculated as $47.14 \%$ 
Crop raiding status by Assamese monkeys (Macaca assamensis) along the Kaligandaki River...

maize, $16.43 \%$ fruits, $11.13 \%$ wheat, $5.72 \%$ millet, 4.58 $\%$ rice, $4.27 \%$ potato, $4.07 \%$ lentil, $1.26 \%$ mustard, 1.14 $\%$ pumpkin, $0.96 \%$ bread, $0.81 \%$ brown lentil, $0.8 \%$ broad beans, $0.6 \%$ sesame, $0.35 \%$ black pulses, $0.2 \%$ dal, $0.14 \%$ cauliflower, and $0.1 \%$ each of tomato, egg, samosa and gram. The percentage of total crop raided was calculated as $30.06 \%$ and the average loss of crop items was calculated as $23.62 \%$ (Fig. 2).

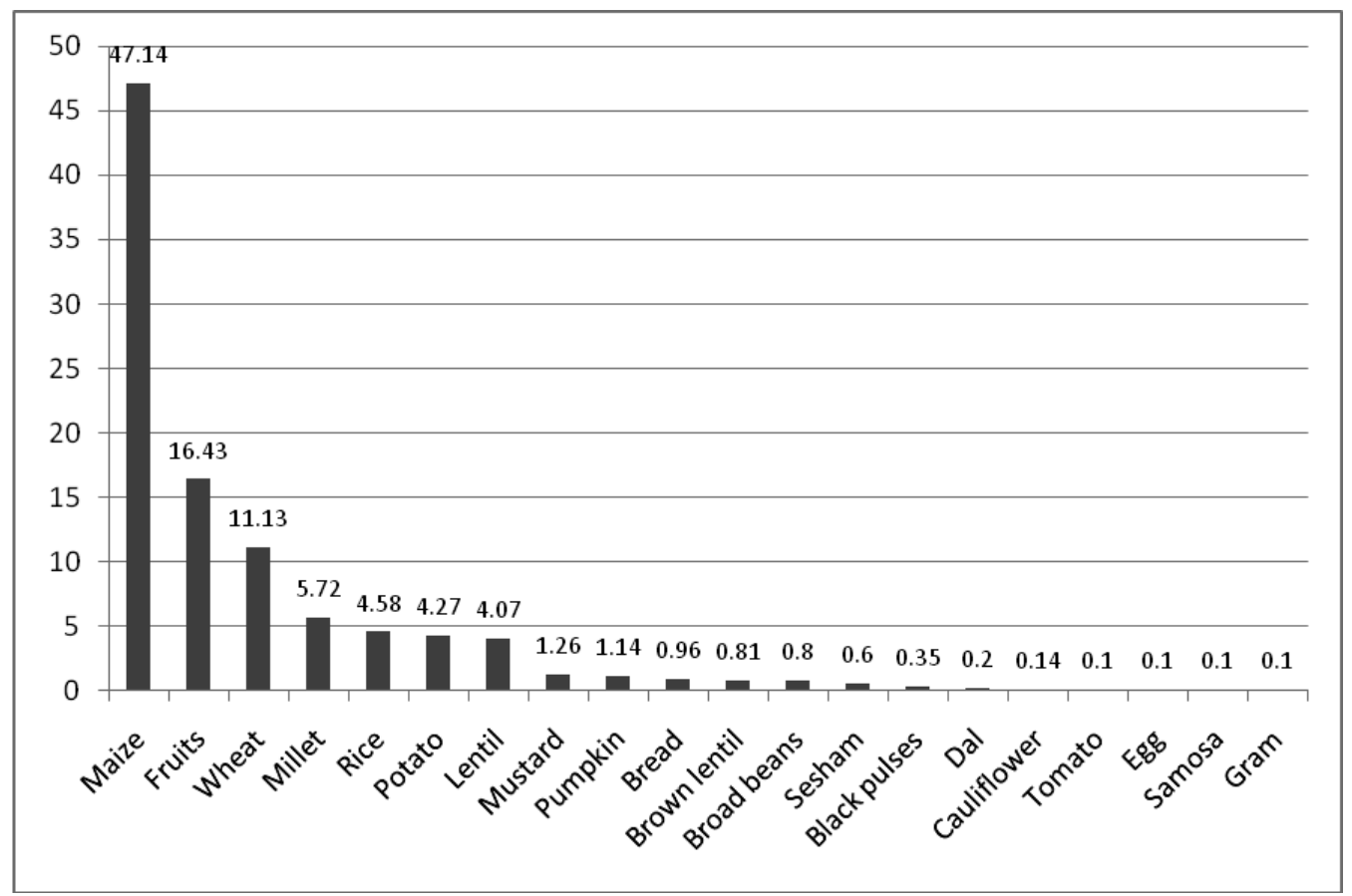

Fig. 2. Percentage of crop raid by Assamese monkeys

\section{DISCUSSION}

Crop damage by the monkey species is very common in Nepal. Upreti (1985) reported that the buckwheat and barley raided by wild animals in Langtang and Rara National Parks. Similarly, Jackson (1990) also recorded the damage to crops by monkeys in the southern boundary of the Makalu-Barun Conservation Area (MBCA). In many parts of the distribution range, anthropogenic habitat alteration has forced the non-human primate into conflict interactions with humans and their livelihood activities, especially through crop raiding (Priston et al. 2012). Crop damage caused by raiding primates is one of the most widespread and common examples of humanprimate conflicts in the areas where local people are mainly subsistence farmers (Hill, 1998). When the supply of natural food is not enough, high quality and easily digested human food is a good alternative form of nutrition for primates, which could be the most important cause of the intensity of crop raiding (Khatun et al. 2013).

It was recorded the highest percentage of crop damage by monkey species was maize $34.12 \%$ which was followed by potato $23.05 \%$, rice $12.01 \%$, fruits $11.68 \%$, wheat $9.57 \%$, millet $5.13 \%$, buckwheat $2.38 \%$ and pulses 2.06 $\%$ in Bandipokhara-Palpa of Nepal (Ghimire 2000). Chalise (1997, 1999) recorded that crop depredation proportions in different crops. In his investigation in
Makalu-Barun Conservation Area (MBCA), the highest percentage of damage on maize was $32 \%$, which followed by potato $24 \%$, rice $14 \%$, fruits $12 \%$, millet 11 $\%$, wheat $4 \%$, buckwheat $2 \%$ and pulses $1 \%$. Chalise (2001) recorded that crop loss in Lakuwa village due to monkey species was maize $7.76 \%$ and pulses $4.14 \%$. During a study in Shiva village, Chalise (2001) noted that crop loss by the monkey species was maize $13.88 \%$, fruits $41.86 \%$, rice $19.16 \%$, wheat $8.97 \%$. Adhikari et al. (2018) recorded the crops raided by monkeys in Ramdi area as maize (35\%), vegetables (20\%), pulses (13\%), fruits $(13 \%)$, potato $(6 \%)$ and rice $(2 \%)$. In this study, it was found that highest raided crop by Assamese monkeys was the maize $47.14 \%$ which was followed by fruits $16.43 \%$, wheat $11.13 \%$, millet $5.72 \%$, rice $4.58 \%$, potato $4.27 \%$, lentil $4.07 \%$, mustard $1.26 \%$, pumpkin $1.14 \%$, bread $0.96 \%$, brown lentil $0.81 \%$, broad beans $0.8 \%$, sesame $0.6 \%$, black pulses $0.35 \%$, dal $0.2 \%$, cauliflower $0.14 \%$, tomato $0.1 \%$, egg $0.1 \%$, samosa 0.1 $\%$ and gram $0.1 \%$. The highest crop damage was found the maize $(47.14 \%)$ and the lowest loss was the tomato $(0.1 \%)$ as well as other cooked food items such as egg $(0.1 \%)$, samosa $(0.1 \%)$ and gram $(0.1 \%)$. The average loss of crop items was found $23.62 \%$. The total crop raided percentage was found $30.06 \%$. Present study shows the highest crop raid maize $(47.14 \%)$ in the Kaligandaki river basin as compared to Ghimire (2000), 
Chalise (1997, 1999, 2001) and Adhikari et al. (2018), those recorded low crop loss in Bandipokhara, Palpa, Makalu-Barun Conservation area (MBCA) and Ramdi, respectively. The main reasons for these differences are due to less availability of natural food plants for the monkeys and destruction of their habitats (constructing Kaligandaki corridor) which tends to move the monkeys to the human settlements and crop fields to raid the crops.

The frequency of crop raiding is affected by the availability of natural food as well as number of individuals of the monkeys in the area. Crop raiding is an essential component of the ecology of primates inhabiting human settlements (Naughton-Treves et al. 1998) but it is likely to minimize the tolerance of subsistence farmers towards conservation of such crop-raider threatened primate species (Khatun et al. 2013). This fact may be useful in predicting the vulnerability of the Assamese monkey survival in Kaligandaki riverside area. Artificial provisioning causes changes in the diet, home range and habitat and even the behavior of the monkey (Southwick et al. 1976). In Ramdi area monkeys are habituated to human because of provisioning of foods, therefore their diet, home range, habitat and behavior are also changed. Most of the respondents believe the scarcity of food, increase in monkey population, loss of habitat, behavioral changes of monkeys due to artificial provisioning by Hindu Pilgrims etc. are the major causes of monkeys turning into crop-raiders. Monkeys living in the habitat with fewer wild food resources are more likely to utilize human settlements and areas around them with dependence on crop foods (Yamada \& Muroyama 2010). The food provided by the Hindu Pilgrims in temple areas of Ramdi might have caused behavioral changes and increased their dependence to provisioned food rather than foraging from the wild. The food supplied in the temples may not be enough and to meet the nutrients requirement the monkeys enter the crop fields, orchards or even the grain storage houses instead of foraging the wild food, which increase the conflicts with local people. Crop raiding by monkey species is one of the serious problems in the village area (Chalise 1997). Although they raid the crops, they also help in dispersal of wild seeds in the forest (Chalise 1999). Monkeys raid the crops, mainly due to the scarcity of wild edible foods and reduction of their habitat. Such situation forces them to survive on human crop field and settlements. The detail assessment of the habitat quality and its management would minimize the human-monkey conflicts and it will be helpful in conservation of the endangered and protected Assamese monkey species along the Kaligandaki riverside of western Nepal.

\section{CONCLUSION}

The highest raided crop by Assamese monkeys was maize $(47.14 \%)$ along the Kaligandaki river basin of western
Nepal. Crop damage by the monkey species is a common problem in the mid-hills of Nepal. Monkeys raid crops, mainly due to the scarcity of wild edible foods and reduction of habitat. Human-monkey conflict in Ramdi area was found to be a serious social problem which may be due to the proximity of forest to the settlements, artificial provisioning, availability of palatable crops and abundance of safe hiding sites on the rocky outcrops on the bank of Kaligandaki River. Under a systematic management scheme, we should educate people on the importance of wildlife including the endangered and protected Assamese monkey species of Nepal.

\section{ACKNOWLEDGEMENTS}

We would like to acknowledge sincerely to Prof. Dr. Tej Bahadur Thapa, Head of Department, Central Department of Zoology, Tribhuvan University, Kirtipur and the members of research committee for their kind cooperation. We are greatly indebted to our field helpers and local villagers of Kaligandaki riverside for their invaluable assistance during our field work. The respondents of the questionnaire survey are greatly acknowledged for providing the valuable information.

\section{REFERENCES}

Adhikari, K., Khanal, L. and Chalise, M.K. 2018. Status and effects of food provisioning on ecology of Assamese monkey (Macaca assamensis) in Ramdi area of Palpa, Nepal. Journal of Institute of Science and Technology 22(2): 183-190.

Bishop, N.H. 1979. Himalayan langurs: temperate colobines. Journal of Human Evolution-USA 8: 251281.

Chalise, M. K. 1998. Study of Assamese monkeys (Macaca assamensis) in Makalu-Barun conservation area, Nepal. A research report submitted to Conservation International, Washington DC, USA.

Chalise, M.K. (2013). Fragmented primate population of Nepal. In: Marsh, L.K. and Chapman, C.A. (eds) Primates in Fragments: Complexity and Resilience, Developments in Primatology: Progress and Prospects, pp. 329-356.

Chalise, M.K. 1995. Comparative study of feeding ecology and behavior of male and female Langurs (Presbytis entellus). PhD Thesis, Central Department of Zoology, Tribhuvan University, Kirtipur, Nepal.

Chalise, M.K. 1997. Monkeys from Makalu-Barun Conservation Area (MBCA). NAHSON Bulletin 7(14): $30-34$

Chalise, M.K. 1999. Some behavioral and ecological aspects of Assamese monkeys (Macaca assamensis) in Makalu-Barun area, Nepal. Journal of Institute of Science and Technology 1: 85-90. 
Crop raiding status by Assamese monkeys (Macaca assamensis) along the Kaligandaki River...

Chalise, M.K. 2000a. Report on the Assamese monkeys (Macaca assamensis) of Nepal. Asian Primates 7(12): 7-11.

Chalise, M.K. 2000b. Crop raiding by wildlife, specially primates and indigenous knowledge of food conservation. Asian Primates 7(3-4): 4-9.

Chalise, M.K. 2003. Assamese monkeys (Macaca assamensis) in Nepal. Primate Conservation. The Journal of the IUCN/SSC Primate Specialist Group, Conservation International, USA 19: 99-107.

Chalise, M.K. 2008. Primate census in Kathmandu and west parts of Nepal. Journal of Natural History Museum 23: 60-64.

Chalise, M.K.; Karki, J.B. and Ghimire, M. 2001. Survey of Assamese monkey in Langtang National Park, Nepal. ASP Bulletin 25(4): 4-5.

Ghimire, S.C. (2000). Study of Rhesus monkeys (Macaca mulatta) of Bandipokhara VDC area, Palpa, Nepal. M.Sc. Thesis, Central Department of Zoology, Tribhuvan University, Kirtipur, Nepal.

Hill, C.M. 1998. Conflicting attitudes towards elephants around the Budongo Forest Reserve, Uganda. Environmental Conservation 26: 218-228.

Jackson, R. 1990. Threatened wildlife, crop and livestock depredation and grazing in the Makalu-Barun conservation area. Makalu-Barun Conservation Project, DNPWC, Nepal. Report No. 12.

Jnawali, S.R., Baral, H.S., Lee, S., Acharya, K.P., Upadhyay, G.P. and Pandey, M. 2011. The status of Nepal mammals: the national red list series. DNPWC, Nepal.

Johnson, R., Teas, J., Bishop, N.H. and Southwick, C.H. 1988. A decade of stability in a Nepalese macaque population. Journal of Mammalogy 69: 178-180.

Khanal, L., Chalise, M., and Jiang, X. (2018). Ecological nice modeling of Himalayan langur (Semnopithecus entellus) in southern flank of the Himalaya. Journal of Institute of Science and Technology 23: 1-9.
Khatun, U.H., Ahsan, M.F. and Roskaft, E. 2013. Local people's perceptions of crop damage by common Langurs (Semnopithecus entellus) and human-langur conflict in Keshabpur of Bangladesh. Environment and Natural Resources Research 3(1): 111-126.

Naughton-Treves, L., Treves, A., Chapman, C. and Wrangham, R. 1998. Temporal patterns of cropraiding by primates: linking food availability in croplands and adjacent forest. Journal of Applied Ecology 35(4): 596-606.

Priston, N.E., Wyper, R.M. and Lee, P.C. 2012. Butonmacaques (Macacaochreatabrunnescens): crops, conflict and behavior on farms. American Journal of Primatology 74(1): 29-36.

Sanjay, M., Douglas, B.J., Wolfgang, D., Ardith, E., Ajith, K., Mewa, S., Feeroz, M.M., Chalise, M.K., Padma, P.S.W. and Sally, W. 2003. Status of south Asian primates: conservation assessment and management plan (CAMP). Workshop report, Zoo Outreach Organization/ CBSG- south Asia, Coimbatore, India, viii+432 pp.

Southwick, C.H., Beg, M.A. and Siddiqui, M.R. 1976. A population survey of Rhesus monkeys in villages, towns and temples of northern India. Ecology 42(3): 538-547.

Southwick, C.H., Teas, J., Richie, R. and Taylor, H. 1982. Ecology and behavior of Rhesus monkeys (Macaca mulatta) in Nepal. National Geographic Society. Research Report 14: 619-630.

Upreti, B.N. 1985. Park people interface problems and new directions. In: Report of international workshop on management of national parks and protected areas of the Hindukush Himalayas. Kathmandu, Nepal, p. 19-24.

Wada, K. 2005. The distribution pattern of Rhesus and Assamese monkeys in Nepal. Primates 46: 115-119.

Yamada, A. and Muroyama, Y. 2010. Effects of vegetation type on habitat use by crop-raiding Japanese macaques during a food- scarce season. Primates 51(2): 159-166. 